\title{
Soft-sediment deformation structures in the sub-Himalayan Middle Siwalik Subgroup, Lish River section, India
}

\author{
1 Department of Geology, Asutosh College, 92, S.P. Mukherjee Road, Kolkata - 700 026, India. *E-mail: kundu.abhik@ gmail.com \\ 2 Department of Geology, University of Pretoria, Pretoria 0002, South Africa; \\ 3 Department of Geology, University of Calcutta, 35, Ballygunge Circular Road, Kolkata - 700 029, India
}

(Received November 11, 2014; Revised accepted April 26, 2015)

The Mio-Pliocene Middle Siwalik Subgroup, in the Lish River Section in the Darjiling District of the Eastern Himalaya, consists of sandstone, mudrocks, heterolithic units and conglomerates preserving six distinct associations of soft-sediment deformation structures at different stratigraphic levels. The foreland basin sediments of the Himalayan orogen were deposited in alluvial fan settings. Deformation structures present are: folds of variable geometry, pseudonodules, water escape features, flame structures and chaotic laminae. Liquefaction and/or fluidization of sediments in the soft state are inferred to have been responsible for the origin of these structures. Both the depositional palaeoenvironment and seismic tremors generated due to thrusting activities in the hinterland situated to the north of the then Middle Siwalik basin contributed to triggering the liquefaction/fluidization and creation of the softsediment deformation structures within the Middle Siwalik sediments.

\section{Introduction}

The still active Himalayan orogenic system which formed due to collision between the Indian and Eurasian plates that was initiated at $\sim 55 \mathrm{Ma}$ (Yin and Harrison, 2000) is a subject for tectonic studies (Valdiya, 1980; Arita, 1983; Nakata, 1989; Yeats and Lillie, 1991; DeCelles et al., 1998; Mukhopadhyay and Mishra, 1999; Bhattacharyya and Mitra, 2009; McQuarrie et al., 2008; Saha, 2013). The Himalayan mountain belt is divided into Higher, Lesser and subHimalaya (Fig. 1a). The sub-Himalayan belt along the frontal part of the Himalayan orogen is occupied by sedimentary rocks of the Siwalik Group which is almost continuous from Pakistan in the west to the Arunachal Pradesh area of India in the east (Gansser, 1964; Yin, 2006). From different sedimentological accounts it is evident that softsediment deformation structures (SSDS) form a very important component of the sedimentary rocks of the Siwalik Group (e.g., Kumar et al., 2005; Singh et al., 2007; Bhakuni et al., 2012). Most of the SSDS reported from the Siwalik Group are interpreted as seismites (Kumar et al., 2005; Singh et al., 2007; Bhakuni et al., 2012; cf. Seilacher, 1969). As a recent example, Kundu et al. (2011) have deduced the soft-sediment deformation structures from the Siwalik succession of the Tista River valley in the Darjiling-Sikkim Himalaya to be seismites. In the Lish River valley, $\sim 3 \mathrm{~km}$ to the east of the Tista valley, the sedimentary rocks of the Middle Siwalik Subgroup preserve various SSDS at different stratigraphic levels. Here the SSDS are more intensely developed, diverse in nature than the structures found in the Siwaliks of the Tista valley. Here in each deformed lamina set/bedset, the prolific development of SSDS is more pronounced than that in Tista valley section. It perhaps suggests that there is heterogeneous development of SSDS along the trend (E-W) of the Siwalik basin in the Darjiling Himalaya. Therefore, the interpretation presented by Kundu et al. (2011) for the SSDS of Tista valley cannot be considered as type development of such structures in the basin. The present exercise is an attempt to elucidate the origin of the SSDS excellently preserved in the Middle Siwalik succession in the Lish River section, in the Darjiling and Jalpaiguri districts of West Bengal, as a further contribution to the inferred regional importance of such features throughout the sub-Himalaya.

\section{Geological setting}

In the Darjiling district the sedimentary rocks of the Siwalik Group occur along the sub-Himalayan belt, to the north of which, quartzite and coal beds of the Gondwana Group are present. The contact between the Siwalik and the Gondwana rocks, represented by a perpetual landslide zone in the Lish valley, is the Main Boundary Thrust (MBT) (Fig. 1b). To the south of the Siwalik succession, recent alluvium of the present day foreland basin is present (Fig. 1b). The Siwalik Group is divided into three Subgroups: (i) Lower Siwalik which is essentially fine- to medium-grained sandstone-dominated, (ii) Middle Siwalik in which medium- to coarse-grained sandstone dominates with subordinate amounts of conglomerates and finer rocks and (iii) Upper Siwalik which is typically conglomeratic with subordinate sandstones (Table 1) (Banerji and Banerji, 1982; Acharyya, 1994). In the area of study, the dominance of mediumand coarse-grained sandstone over the finer grained rocks and 


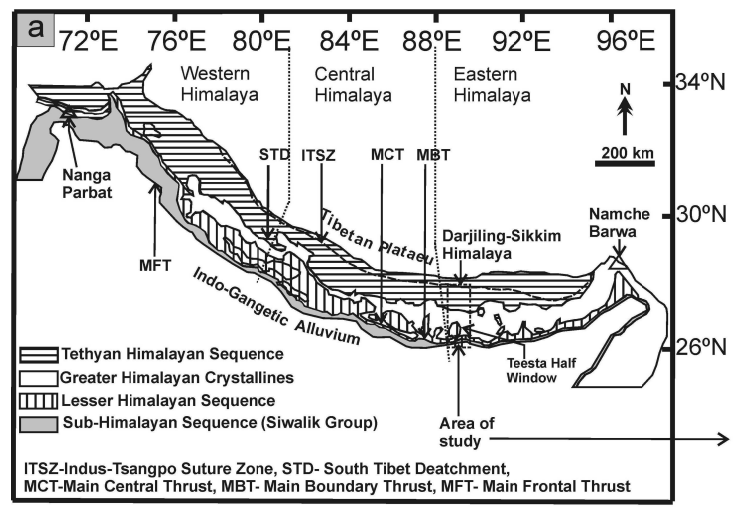

Figure 1. (a) Generalised geological map of the Himalayan orogenic belt (after Yin, 2006) showing the area of study (marked by box); (b) Geological map of the area of study.
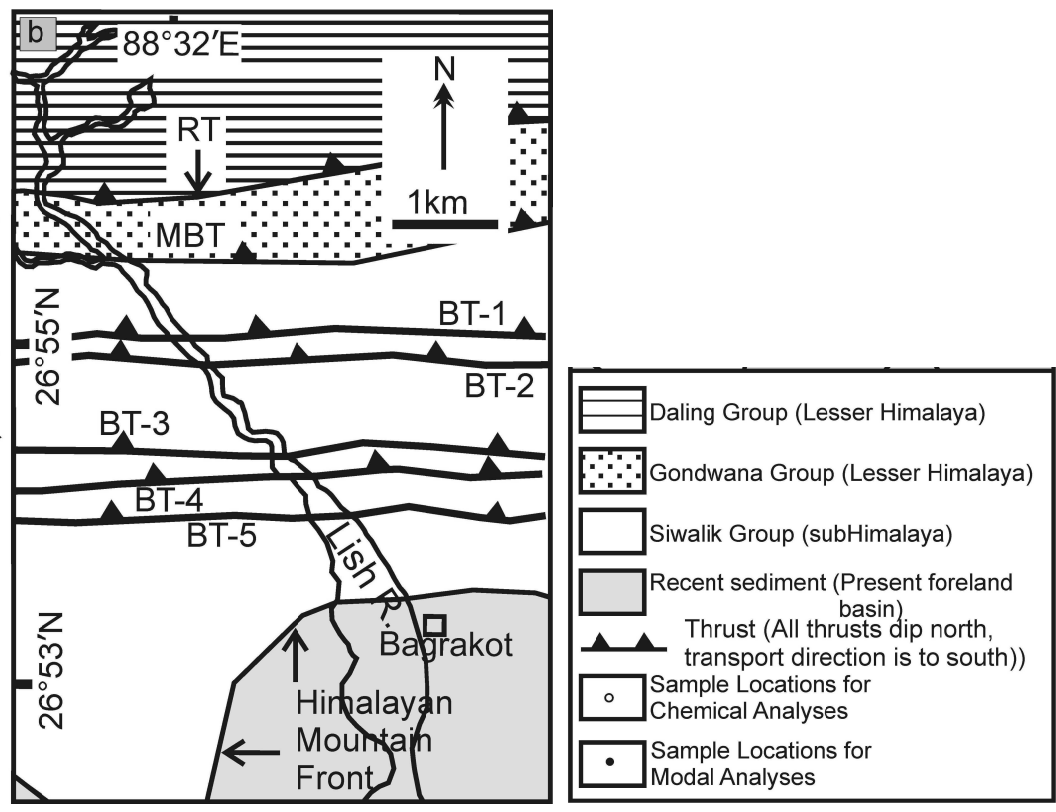

also over conglomerates clearly indicates its Middle Siwalik affinity.

The Siwalik succession of the eastern sub-Himalayan area is repeated by thrust faults (Mukul, 2000; Kundu et al., 2011). In the Lish River valley the repeated sequence of Siwalik sedimentary rocks is $\sim 3 \mathrm{~km}$ wide along N-S transects (Fig. 1b). Five north dipping thrusts (BT-1 to BT5, Fig. 1b) have punctuated the sequence. The $\sim 250 \mathrm{~m}$ thick BT-2 thrust sheet is the thickest of the thrust sheets and therefore is considered as representative of the Middle Siwalik sequence in the Lish valley. The sequence consists of coarse-, medium- and finegrained sandstone, siltstone, mudrocks (both mudstone and mudshale; cf. Ingram, 1954; Stow, 1981), and heterolithic units (laminated sandstone intercalated with mudstone and siltstone; cf. Reineck and Singh, 1980; Demicco and Hardie, 1994) and conglomerate (Fig. 2). The detailed sedimentological nature of the Siwalik rocks of the Tista and Lish River valleys was first described by Banerji and Banerji (1982). They have shown the presence of fine- to coarse-grained sandstones, siltstone and shale. Banerji and Banerji (1982) have proposed an alluvial fan depositional model for the Siwalik sediments of the Darjiling area. They also found mineralogical and textural similarities between the Siwalik rocks and recent sediments of the Tista River. Kundu et al. (2012), through facies analysis, have suggested an alluvial fan setting in a tectonically active environment for the Middle Siwalik sedimentary rocks of the Tista valley, lying to the west of the Lish valley. In the present study area nine sedimentary facies have been identified. These are: plane laminated or tabular cross-stratified medium-grained sandstone (mostly arkosic) facies; trough cross-stratified coarse- to medium-grained pebbly sandstone (litharenites and arkose) facies; pebble-free coarse- to medium-grained sandstone (dominantly arkosic, some litharenites) facies with sheet geometry; plane laminated and small scale rippled fine-grained sandstone (mostly arkosic) facies; cross-stratified matrix-supported conglomerate facies; matrix-supported massive conglomerate facies; clast-supported cross-stratified conglomerate facies; matrix-supported

Table 1. Stratigraphic succession of eastern Himalaya, Darjiling-Sikkim region (after Sinha Roy, 1967; Acharyya and Shastry, 1979; Acharyya, 1994; Matin and Mukul, 2010).

\begin{tabular}{|c|c|c|c|}
\hline Geologic Time & Group & Subgroup & Formation and Lithology \\
\hline \multirow{2}{*}{$\begin{array}{l}\text { Late Miocene } \\
\text { to Pliocene }\end{array}$} & \multirow{2}{*}{$\begin{array}{l}\text { Siwalik } \\
\text { Group }\end{array}$} & $\begin{array}{l}\text { Upper } \\
\text { Siwalik }\end{array}$ & $\begin{array}{l}\text { Murti Boulder bed (crude immature conglomerate) Parbu Grit (pebbly } \\
\text { sandstone and coarse- to medium-grained sandstone) }\end{array}$ \\
\hline & & $\begin{array}{l}\text { Middle } \\
\text { Siwalik }\end{array}$ & $\begin{array}{l}\text { Geabdat Sandstone (medium- to coarse- grained sandstone and shale, } \\
\text { pebble beds and marl) }\end{array}$ \\
\hline $\begin{array}{l}\text { Early to Middle } \\
\text { Miocene }\end{array}$ & & $\begin{array}{l}\text { Lower } \\
\text { Siwalik }\end{array}$ & $\begin{array}{l}\text { Chunabati Formation (fine- to medium-grained sandstone, siltstone, } \\
\text { mudstone, marl and conglomerate) }\end{array}$ \\
\hline Upper Permian & \multirow{2}{*}{$\begin{array}{l}\text { Gondwana } \\
\text { Group }\end{array}$} & Damuda & Sandstone, carbonaceous shale and coal \\
\hline Lower Permian & & $\begin{array}{l}\text { Rangit } \\
\text { Pebble-Shale }\end{array}$ & Diamictite, rythmite, quartzite and marl \\
\hline \multirow{3}{*}{ Precambrian } & Daling Group & & Buxa Formation, Reyang Formation, Daling Formation \\
\hline & Paro Group & & Parametamorphites with migmatitic and foliated granitic gneiss \\
\hline & Darjiling Gneiss & & Two-mica migmatitic gneiss \\
\hline
\end{tabular}




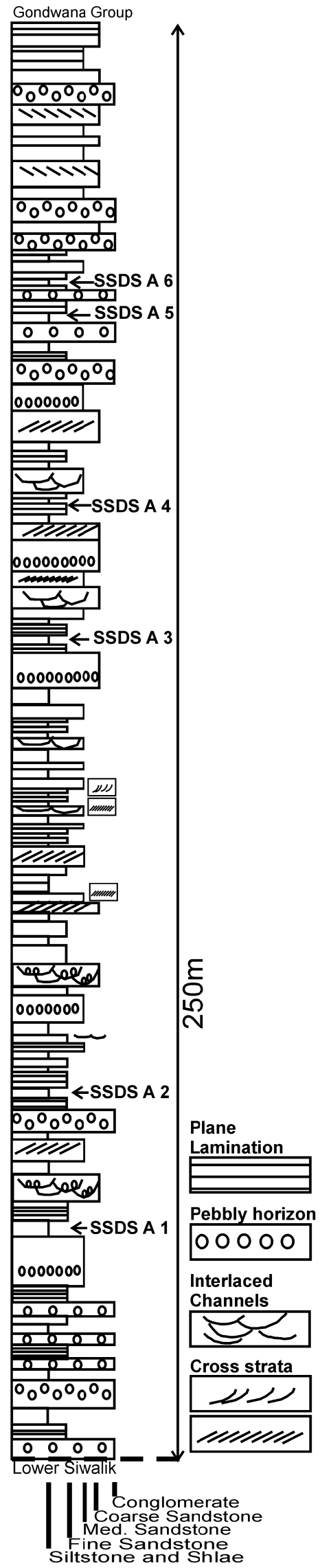

Figure 2. Litholog of Middle Siwalik Subgroup in the Lish River section. The occurrences of SSDS associations are marked, e.g. SSDS A1 stands for SSDS Association 1. graded bedded and channel-structured conglomerate facies; heterolithic facies of two distinct types: (i) laminated fine sandstonesiltstone-mudstone (cf, Stow, 1981) and (ii) composite bedsets of siltstone and mud-shale, completely devoid of sandstone. A detailed analysis of facies and facies associations in order to explain the depositional environment of the sediments is presented in Kundu (2012 and is now under revision in another publication).

\section{Soft-sediment deformation structures}

SSDS are preserved in different heterolithic bed sets and also in fine-grained sandstones. The deformation structures are folds of varied geometries, flame structures, pseudonodules, water escape structures and breached laminae. In all of the deformed horizons different types SSDS are present in close spatial association with each other. Each of these associations of SSDS is described separately and also interpreted separately as there remains every possibility for distinct sediment horizons to have been deformed by different geological processes (Wheeler, 2002; Moretti and van Loon, 2014 and references therein).

\section{SSDS Association 1}

A set of laminae within a heterolithic laminaset preserves several SSDS in close association (Fig. 3). The most prominent SSDS in this horizon is a broad synform ( $\mathrm{S}$ in Fig. 3 ) with $0.7 \mathrm{~m}$ amplitude and moderately inclined limbs, followed upward by an inverted mushroom-shaped fold ( $\mathrm{M}$ in Fig. 3). A tight neutral fold ( $\mathrm{N}$ in Fig. 3 ) is in close association with these structures. Asymmetric folds, dextral from east (D in Fig. 3), comparatively smaller than other structures in this association, are present immediately above the mushroom-shaped and tight neutral folds. The $\mathrm{D}, \mathrm{M}$ and $\mathrm{N}$ folds are southward closing synforms and all the folds in this deformed sediment package have southerly (in conformity with palaeocurrent direction, Banerji and Banerji, 1982) sloping axial traces and east-west trending axes. Antiformal closures of the folds are characteristically absent. The laminae above and below this deformed heterolithic lamina set, are of similar lithological character and are undeformed. From the presence of folds, which are signatures of a compressive regime, their dimensions, similar orientation of closures of different folds, southward slope of fold axial traces indicating down-the-slope movement, absence of upward (antiformal) closures possibly indicating consecutive sediment movements obliterating immediately earlier formed antiforms, and from the presence of undeformed beds above (U in Fig. 3) and below, the folds in this association of SSDS are considered as slump folds (cf. Collinson and Thompson, 1982; Allen, 1984; Demicco and Hardy, 1994; Sarkar et al., 1995; 2014; Bose et al., 1997). The observed absence of the same set of laminae within adjacent folds, absence of folds of smaller amplitudes (cmscale), absence of upright axial planes also support interpretation of the folds in this association as slump folds and not as convolute folds (cf. Demicco and Hardy, 1994 and references therein; Sarkar et al., 1995; 2014; Bose et al., 1997).

\section{SSDS Association 2}

A heterolithic lamina set, essentially plane laminated, preserves (i) a series of asymmetric folds, sinistral from west with southwardly oriented closure in conformity with the dominant palaeocurrent 


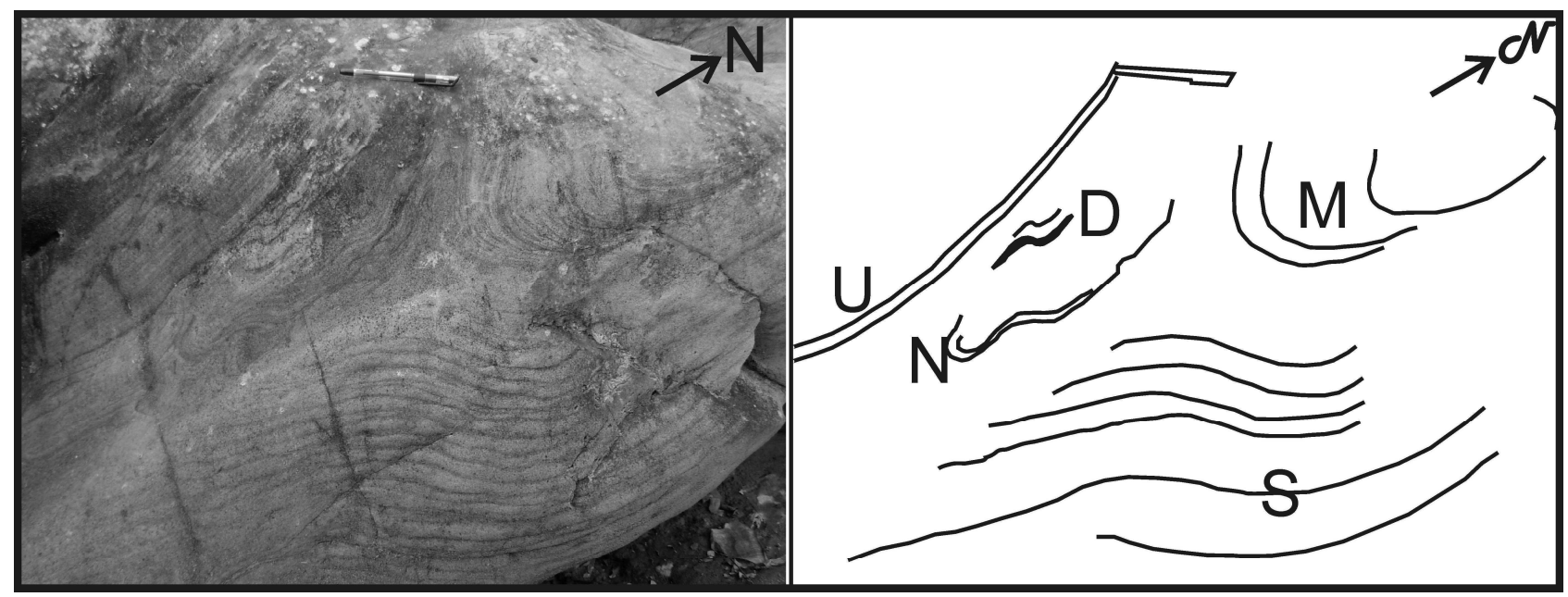

Figure 3. SSDS Association 1 in vertical section and in inclined sections (upper-left and upper-right corners of the photograph): S-broad synform, M-mushroom shaped fold, $N$ - neutral fold, D-dextral folds. Note that $D, M$ and $N$ show southward closure. $U$-undeformed lamina set. Pen for scale $=14 \mathrm{~cm}$.

direction (S in Fig. 4), with E-W trending sub horizontal fold axes and northerly steeply dipping axial planes; and (ii) a series of asymmetric folds, dextral from west (D in Fig. 4), immediately below the other (S) series of folds. These folds also have E-W trending subhorizontal axes but the axial planes are steeply dipping towards the south. The southward tail of this series of folds is recumbently folded ( $\mathrm{R}$ in Fig. 4). Other extensions of these folded lamina sets are undeformed (U in Fig. 4). This deformed lamina set is overlain by an undeformed plane laminated sandstone-siltstone bed set ( $\mathrm{P}$ in Fig. 4) and is underlain by an undeformed cross-bedded sandstone-siltstone bed set ( $\mathrm{C}$ in Fig. 4).

Any evidence of erosion of the deformed layer is also absent as the closures of the upper series of folds are intact.

\section{SSDS Association 3}

In a heterolithic composite bed set, folds and water-escape structures associated with breached laminae are preserved (Fig. 5). The water escape zone is filled by mudstone (W in Fig. 5). Sandstone- mudstone laminae at the margin of the water escape structure are curved upward. The folds are at the lower part of this sediment package and are asymmetric disharmonic folds with moderately northerly dipping axial planes (D in Fig. 5). The mudstone laminae at the limbs are tapered and terminate at a distance of a few $\mathrm{cm}$ away from the fold hinge. Below the water escape pipe, mudstone-sandstone laminae are bent to form a tepee structure ( $\mathrm{T}$ in Fig. 5). The continuity of the laminae is lost near the tepee and the base of the water escape structure and the sedimentary rock exhibits chaotic lamination ( $\mathrm{C}$ in Fig. 5). This association is sandwiched between undeformed bed sets ( $U$ in Fig. 5: overlying undeformed plane laminated unit).

\section{SSDS Association 4}

In a thick fine-grained sandstone bed, convolute folds with broad hinged synformal and tight antiformal closure (cf. Bose et al., 1997) are preserved (Fig. 6). The amplitudes of the folds vary within 15 to $27 \mathrm{~cm}$. The laminae beyond the western limb are almost undeformed while the eastern limb dies out into the massive part of the bed. The

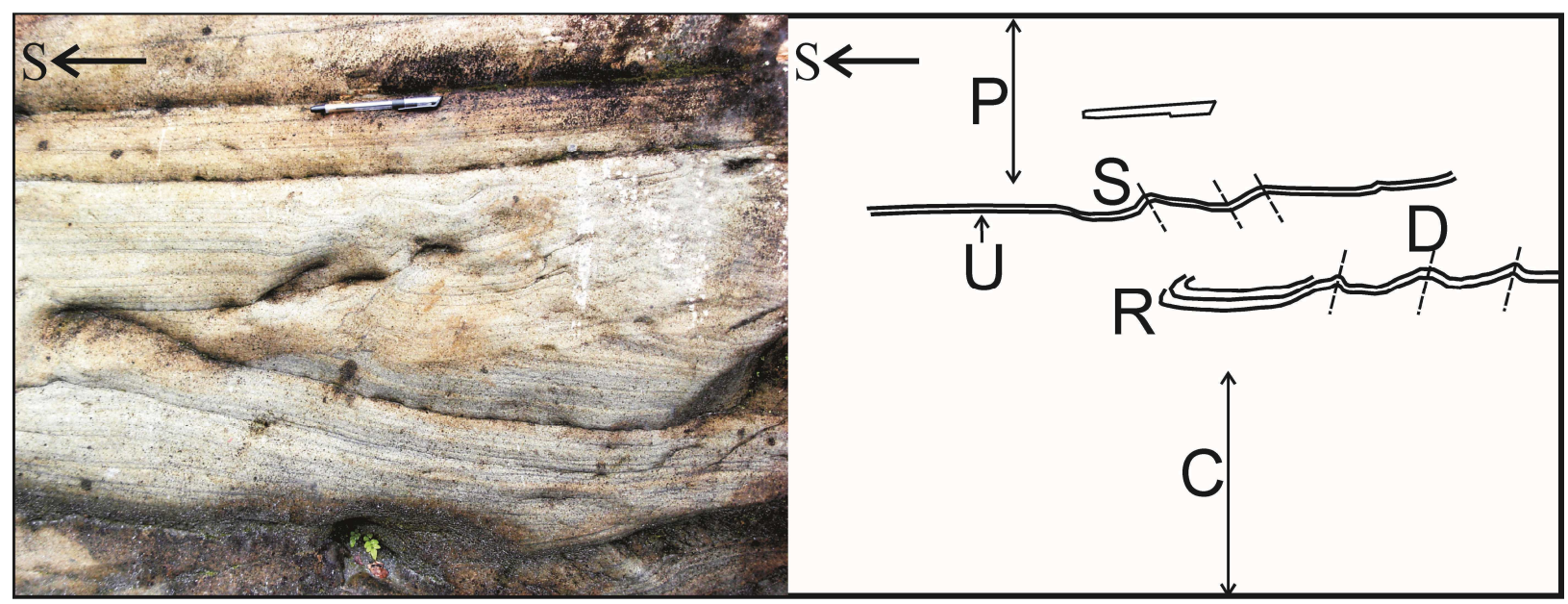

Figure 4. SSDS Association 2 in vertical section: S-series of asymmetric folds (sinistral from west), D-series of asymmetric folds (dextral from west) with recumbent fold at the southern extremity $(R), U$-undeformed part of folded laminae, $P$-undeformed plane laminated unit overlying Association 2, C-undeformed cross-bedded unit underlying Association 2. Pen for scale $=14 \mathrm{~cm}$. South direction indicated by arrow and $S$. 


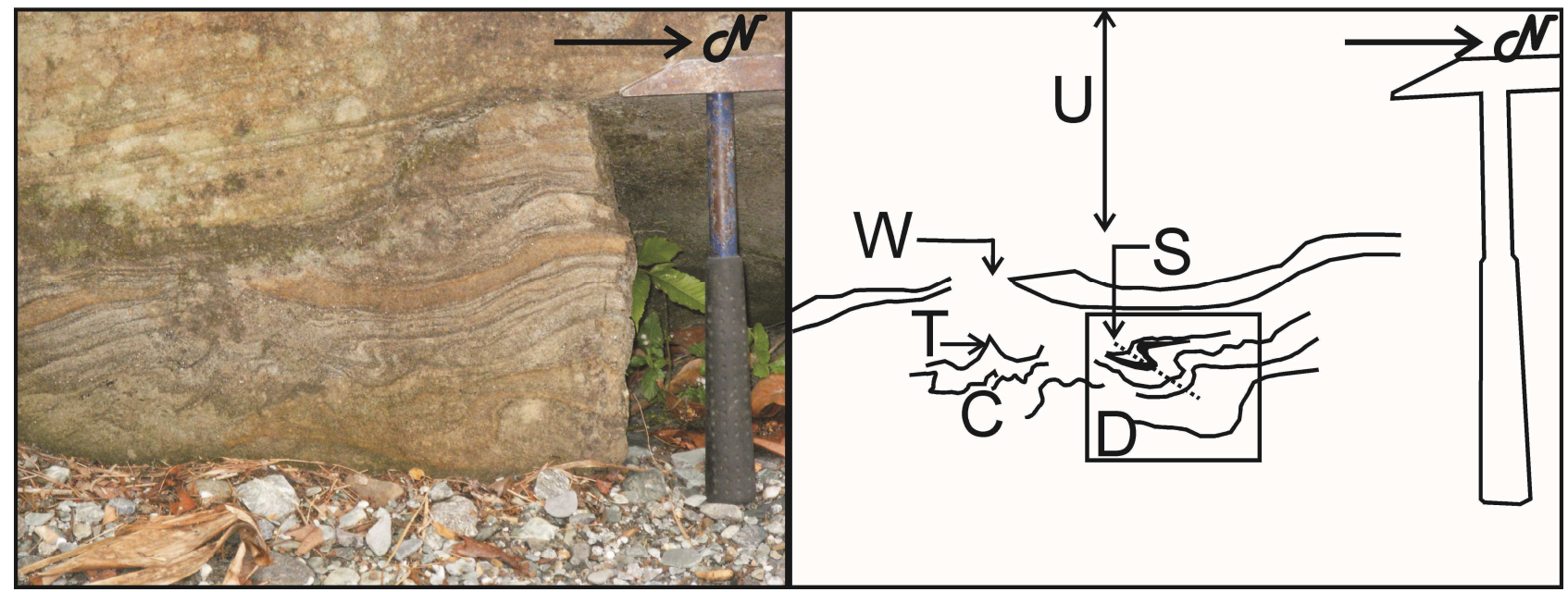

Figure 5. SSDS Association 3 in vertical section: W-mud-filled breached portion of laminae due to water escape, D-asymmetric disharmonic folds with moderately northerly dipping axial planes, $C$-chaotic lamination, T-tepee like structure, U-undeformed plane laminated unit overlying Association 3. Hammer for scale $=45 \mathrm{~cm}$.

limbs and axial planes of the folds are steep to sub-vertical to vertical. The relatively less prominent antiformal closures are much shorter in wavelength. The antiformal hinges are often truncated by the overlying sedimentary layer.

\section{SSDS Association 5}

Within a sandstone bed of about $1 \mathrm{~m}$ thickness, an $\sim 10 \mathrm{~cm}$ thick discrete set of sandstone - mudstone laminae is folded into an antiform (A in Fig.7a) to the north and a synform ( $\mathrm{S}$ in Fig.7a) to the south and are pinched and die out to the south. Only a few centimetres south of this synform the lamination is chaotic (C in Fig. 7a). In close proximity to these structures another discrete zone of sandstone - mudstone laminae is folded into a gently dipping neutral fold with sidewise closure (Fig. 7b). The upper limb of the fold is moderately dipping to the south and the lower limb is steeply dipping towards the north. The lower limb vanishes into featureless sandstone at $\sim 25 \mathrm{~cm}$ below the hinge. The bed is sandwiched between undeformed beds. The overlying bed is undeformed plane laminated fine-grained sandstone.

\section{SSDS Association 6}

In a heterolithic lamina set various SSDS are preserved within a few square metres-sized area of outcrop. These deformation structures are flames, disharmonic folds, chaotic lamination and pseudonodules. The flames ( $\mathrm{F}$ in Fig. 8a) involve curving of both sandstone and mudstone layers. The crest of the flame is bent to the north, i.e. against the recorded southward palaeoslope (cf. Banerji and Banerji, 1982). Folds are restricted to only a set of a few individual laminae within the laminaset ( $\mathrm{D}$ in Fig. 8b). The folds are very small in amplitude with blunt and thickened hinges resembling a sectional view of convolute folds (Bose et al., 1997). A mass of a three-lobed dumbbellshaped nodule of sandstone is present just below the folds (P in Fig. $8 \mathrm{~b})$. This nodule has a tail towards the north. The southern lobe of the dumbbell is the largest. Faint discontinuous traces of laminae are preserved within the nodule lobes and hence these can be regarded as pseudonodules, where individual lobes of the nodule either have not lost contact between them or have amalgamated in the deformational process. Chaotic laminae (C in Fig. 8 b) are also present.

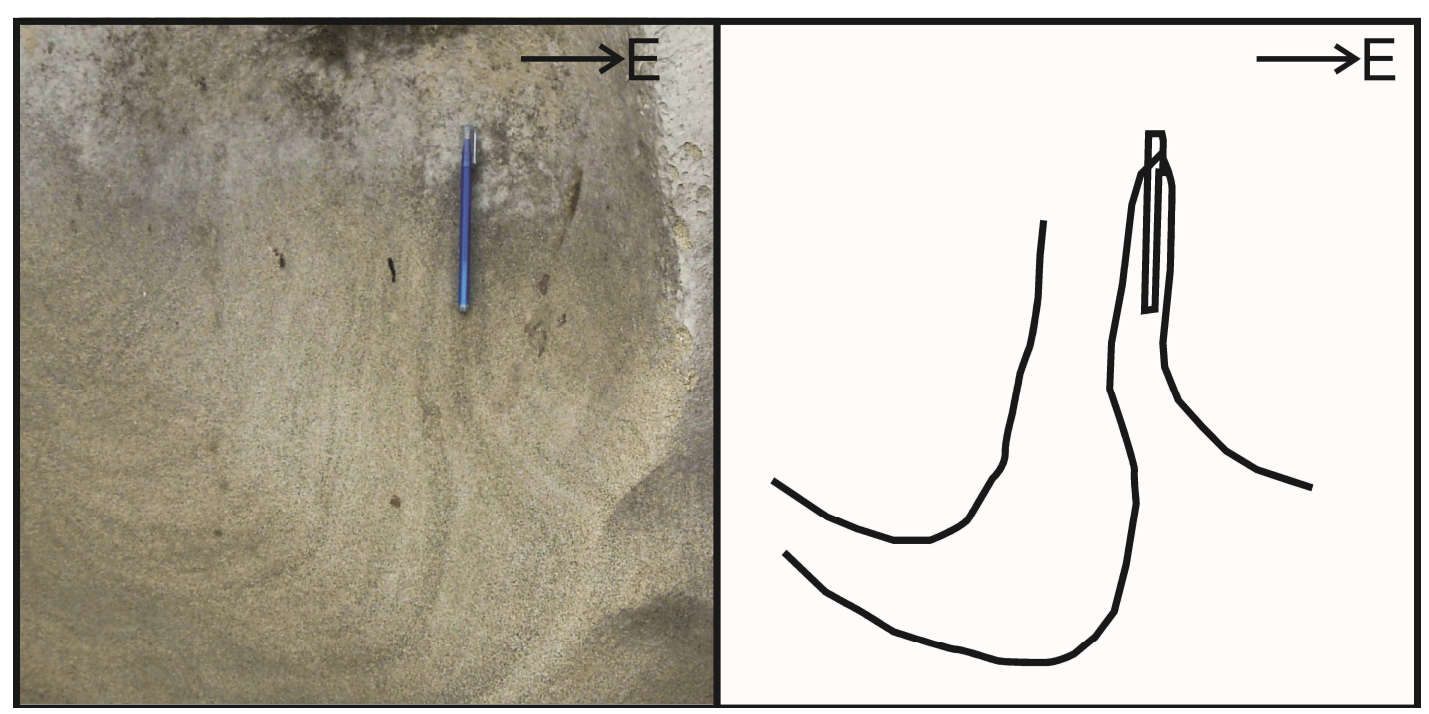

Figure 6. SSDS Association 4 in vertical section: broad synforms and a sharp hinged antiform. The upper lamina is truncated near the hinge by the overlying strata. Pen for scale $=14 \mathrm{~cm}$. 

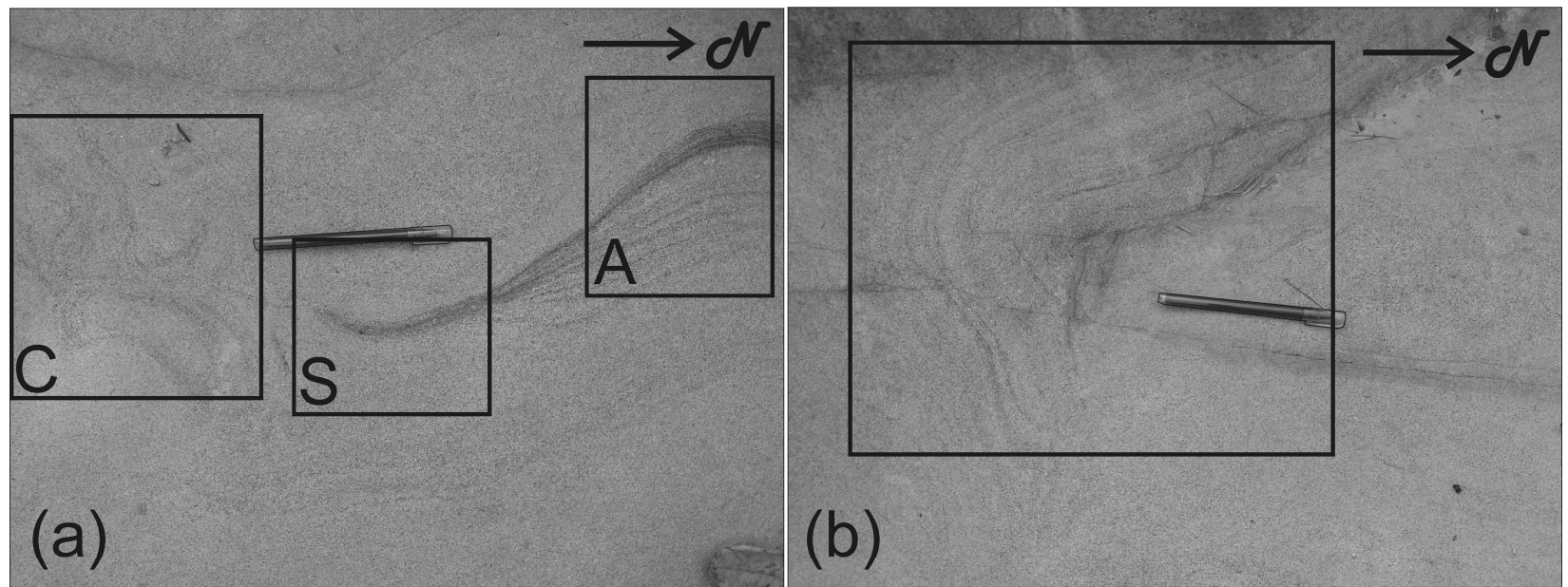

Figure 7. SSDS Association 5 in vertical section: (a) S-synform, A-antiform, C-chaotic laminae, (b) neutral fold. Pen for scale = $14 \mathrm{~cm}$.

\section{Discussion}

\section{Origin of associations of SSDS}

\section{SSDS Association 1}

Slump folds may develop due to slope-controlled gravitational movement of unconsolidated sediment (Mills, 1983; Bose et al., 1997; Sarkar et al., 2014), by large-scale water movements (Siegenthaler et al., 1987) or due to earthquake tremor (Spalluto et al., 2007;
Aboumaria et al., 2009). It is likely that rapid down-slope movement of sediment would deform the underlying sediment if it is unconsolidated. In the present area no deformation signature is attested in the sediment layer underlying the deformed laminae. Neither is even any signature of erosion observed. The folds, though are of different sizes, have axes of similar trend and axial planes with similar direction of slope. According to Simms (2003) penecontemporaneous folds with fold axes oriented in similar fashion develop due to earthquake shocks. Moreover, the presence of various types of folds in close association may also indicate seismic-shock induced
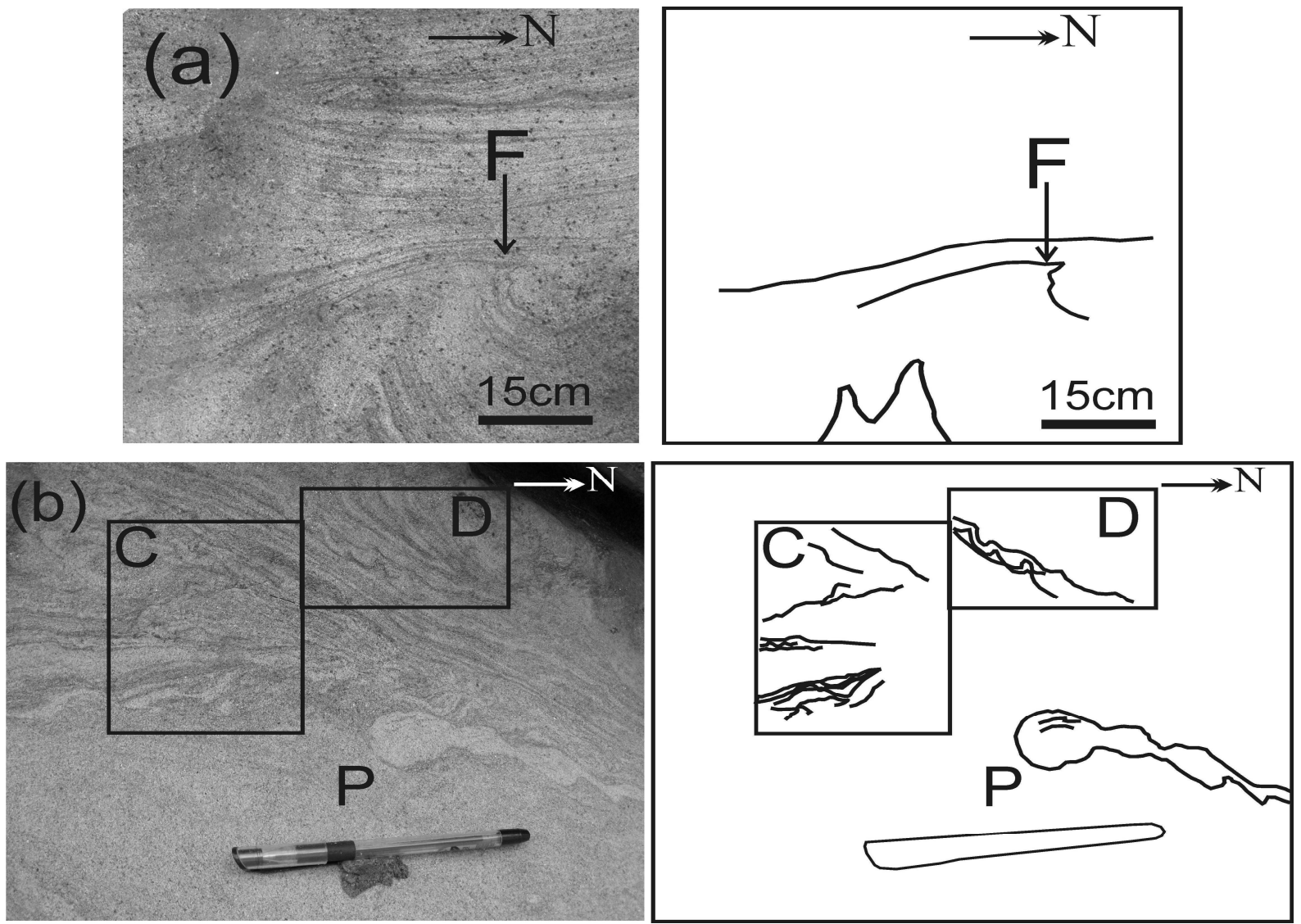

Figure 8. SSDS Association 6: (a) Vertical section. F-flame structure; (b) Section inclined to NE. P-pseudonodule, C-chaotic laminae, Ddisharmonic folds. Pen for scale $=14 \mathrm{~cm}$. 
liquefaction followed by fluidization and mass flow in a plastic state (Dzulynski and Smith, 1963; Collinson and Thompson, 1982; Bhattacharya and Bandyopadhyay, 1998; Rajchl, 1999; Wang et al., 2010). The restricted presence of these soft-sediment deformation structures between overlying and underlying undeformed fine-grained sedimentary beds therefore, supports earthquake induced liquefactionfluidization (cf., Sarkar et al., 1995; 2014; Bose et al., 1997). However, lateral extent of the deformed horizon cannot be traced due to inaccessibility; absence of related data alone cannot exclude the possibility of earthquake trigger (Moretti and van Loon, 2014).

\section{SSDS Association 2}

In this association folds with similar geometry but oppositely oriented closures and axial planes are preserved. Laminae may be folded by an autokinetic process involving the process of sedimentation itself or by an allokinetic process involving an earthquake trigger (Leeder, 1987; Røe and Hermansen, 2006). Alluvial fans are an ideal setting for the genesis of fluvial process-induced soft-sediment deformation (Zieliñski and Van Loon, 1999a; b; 2000; Went, 2005). If the Middle Siwalik layer-bound folds had been formed by channel processes in an alluvial fan where rhythmic reversal of flow direction was absent, it is likely that folds would have had closures with similar orientation. It is also likely that the fold crests would attest to erosion if any water flow with enough energy to liquefy and/or erode a sediment layer had been active above the sediments. On the contrary the presence of an undeformed thin sandstone-siltstone interlaminated horizon over the deformed sediment package suggests a low energy fluid flow unable to liquefy and deform the underlying sediment. Overturning of laminae into recumbent folds may also be a result of liquefaction of sediment due to earthquake or the effect of drag of sand-loaded flow over the sediment substrate (McKee et al., 1962; Døe and Dott, 1980; Owen, 1995; Røe and Hermansen, 2006). The horizon studied here contains various SSDS together, SSDS associations similar to which have been recognised as seismites (Bose et al., 1997; Rodriguez-Pascua et al., 2000; Wheeler, 2002). The lateral extent of the horizon with SSDS, which according to some opinions is a mandatory criterion for establishing SSDS as seismites (Sims, 1975; Hilbert-Wolf et al., 2009; Owen and Moretti, 2011; Owen et al., 2011 and references therein) and to others (Moretti and van Loon, 2014) it is not, could not be established mainly due to inaccessibility and vegetation cover. However, the possibility of earthquake induced liquefaction is strengthened by the presence of undeformed beds above and below the deformed horizon (Cojan and Thiry, 1992; HilbertWolf et al., 2009). The presence of folds in restricted lamina sets points to momentary disturbances, likely earthquakes. Two different lamina sets with varying styles of folding possibly suggest different earthquake events in quick succession, or possibly result from aftershocks.

\section{SSDS Association 3}

Water escape structures can form if liquefied sediment migrates upward through cracks (Collinson and Thompson, 1982). This upward migration can develop shear stress which is responsible for snapping and bending of laminae at the margin of the water escape pipe (Tasgin and Turkmen, 2009 and references therein). In the present example, just below the escape pipes filled by mud, tepee structures with upward-directed apices point to an upward drag towards the void due to fluidisation through the water escape pipe. The folds have varied closure orientations and might thus not have formed by fluvial (autokinetic) processes. The folds across which lamination is not destroyed are signatures of deformation in a hydroplastic state facilitated by liquefaction (Bhattacharya and Bandyopadhyay, 1998; Rajchl, 1999; Jones and Omoto, 2000; Wang et al., 2010). The chaotic portion of the bedset in close association with these structures indicates intense liquefaction of this portion of sediment in a softstate and concomitant movement of sediment particles that destroyed the primary structure. Therefore, all these structures taken together cannot support a fluid flow above the sediment, directly in contact with the sediment, as having been responsible for triggering the deformation. Earthquake tremors are likely causes of formation of such water escape structures where gravitational pull or overloading is normally not responsible (Lowe, 1975; Moretti et al., 1999). Several SSDS present together, restricted presence of the deformed bed between undeformed overlying and underlying beds, absence of overlying erosion surface, presence of fine sandstone or finer-grained sediment above together suggest an earthquake trigger (Bhattacharya and Bandyopadhyay, 1998; Wheeler, 2002; Kundu and Goswami, 2008).

\section{SSDS Association 4}

Folding of sediment within a particular horizon may happen due to seismic shaking (Schnellmann et al., 2002; Spalluto et al., 2007; Aboumaria et al., 2009) but such folds are commonly associated with other SSDS. The absence of any other SSDS with these convolute folds (cf. Bose et al., 1997) in Association 4 imposes a restriction on interpreting the structures as seismites. The folds might have formed due to slope-bound downward movement of liquefied sediment in a plastic state (cf. Bhattacharya and Bandyopadhyay, 1998; Tasgin and Turkmen, 2009). The scanty presence of the folds points to slope controlled flow of sediment load. Alluvial fans are regarded as a favourable setting for the origin of SSDS (Went 2005; Van Loon, 2009). The rocks in the present study have been interpreted as having been deposited in an alluvial fan palaeoenvironment (Banerji and Banerji, 1982; Kundu, 2012). As mass flow deposition is a common phenomenon in this environment and irregular sedimentation is controlled by unstable density gradients due to rapid fluctuation of stream energy and sediment load (Plint and Wadsworth, 2003), it is likely that these folds were formed by channel processes under control of a favourable slope (Mills, 1983; Bose et al., 1997) and influenced by large-scale water movements (Siegenthaler et al., 1987). The lateral continuity of the deformed horizon, which is one of the criteria for a deformed bed to be a candidate for hosting seismites (Sims, 1975; Hilbert-Wolf et al., 2009; Owen and Moretti, 2011; Owen et al., 2011 and references therein), though could not be tested due to the same reason mentioned earlier: the rarity of the massive fine-grained sandstone facies as host of SSDS in the area of study and the lone presence of the fold without any associated structure of different geometry establishes it as a non-seismic structure.

\section{SSDS Association 5}

The sand-mud interlamination in a massive bed must logically be a product of differential compaction and liquefaction. Probably the entire bed was not liquefied and thus transport of the liquefied sediment was restricted up to a specific level within the sediment. At 
this level, with ensuing quiescence, the sediment was resettled by separation of the sand and mud under the action of gravity. Recurrent disturbance might have caused repetitive liquefaction and resettling of sand-mud. This process was favoured by the physical character of the sediment in this portion of the massive sand bed. The expulsion of pore water, the phenomenon that is suggested to be responsible for formation of chaotic layering (Williams, 1970; Owen, 1995) was most likely triggered by an external event, which may have been an earthquake. The presence of different deformation structures like chaotic arrangement of laminae, and two completely different types of folds in close association within the same sediment horizon also suggest that the liquefaction was due to seismic shock and not due to fluvial traction by a sand-laden flow on the top of the deformed bed. This is also substantiated by the absence of current structures above this deformed horizon. The observed presence of undeformed fine sedimentary rock on the top of the association excludes the possibility of loading from the top.

\section{SSDS Association 6}

Differential dynamic viscosity of the different constituent materials in heterolithic horizons may lead to formation of flames (Neuwerth et al., 2006). According to Collinson and Thompson (1982) flames may form by guided fluidization of layers having contrasting densities. The studied flames are bent to the north, i.e. opposite to the palaeoslope, which was to the south (cf. Banerji and Banerji, 1982; Kundu, 2012). This in turn suggests that fluvial drag was not responsible for formation as well as northward bending of the flames (cf. Bose et al., 1997). The role of differential loading and concomitant liquefaction as suggested by some authors (cf. Dasgupta, 1998) can also be ruled out because of the absence of deformation in the overlying fine-grained layer and absence of scour in the upper bounding surface of the deformed sediments. Earthquake induced liquefaction, fluidization and resultant expulsion of pore water lead to formation of folds in sediments behaving hydro-plastically (Cojan and Thiry, 1992; Owen, 1996; Bhattacharya and Bandyopadhyay, 1998; Samaila et al., 2006). Unbroken tops of the folds rule out the role of flowing water (Selley, 1970). The dumbbell-shaped pseudonodule was formed possibly by separation of sand from the fluidized sediment due to differential compaction. The absence of features indicating load from the top suggests this compaction was due to external shock like an earthquake. The presence of different SSDS together in the same bed set also suggests an earthquake trigger (Wheeler, 2002).

\section{The regional picture and significance of the study area}

The Siwalik sedimentary rocks in most of the areas along the Himalayan range are interpreted as fluvial (Nakayama and Ulak, 1999; Brozovic and Burbank, 2000; Sharma et al., 2002) and alluvial fan sediments (Banerji and Banerji, 1982; Thomas et al., 2002; Kumar et al., 2003; Kundu et al., 2012) accumulated by channels draining the tectonically active hinterland to the north. The alluvial fan setting is a common environment where channel process induced soft-sediment deformation takes place (Went, 2005; Van Loon, 2009). The fan development in the Siwalik basin on the Himalayan foreland was concomitant with the thrust propagation (Raiverman, 2002).
The Siwalik basin was the Mio-Pliocene foreland basin of the active Himalayan orogen (Yin, 2006 and references therein). The Siwalik sedimentation took place between $\sim 11$ Ma and 7 Ma during and after the uplift of the Greater Himalayan Crystalline Complex (GHCC) (Sangode et al., 1996; Meigs et al., 1995; DeCelles et al., 1998; White et al., 2001, Ranjan and Banerjee, 2009) and also during the uplift of the Lesser Himalaya (Yin, 2006 and references therein; Ranjan and Banerjee, 2009). The Middle Siwalik basins in the Darjiling Himalaya received sediments from both the GHCC and the Daling Group of rocks of the Lesser Himalaya (Raina, 1976; Kundu et al., 2012). Development of fans should have passed through tectonically active phases of thrust movements when the mountain front advanced to the south into the foreland and intermediate tectonically quiet phases with the fans experiencing erosional activity. During the sedimentation in Siwalik basins in the Eastern Himalaya the phases of seismicity were possibly induced by activities along the Main Detachment Fault, the South Tibet Detachment, Main Central Thrust, Lesser Himalayan thrusts and the north-south trending rifts (Harrison et al., 1995; Edwards and Harrison, 1997; Huyghe et al., 2001). Meigs et al. (1995) suggested a Mid-Late Miocene age for the MBT which has brought the Lesser Himalayan metasediments over the Siwalik sediments. Therefore the earthquakes generated from the activities of MBT were almost coeval with Middle Siwalik sedimentation and must have influenced the deformation of the Siwalik sediments.

A number of facts, namely: that the sedimentary rocks preserving the SSDS were deposited in the foreland basin of an tectonically active orogen in the vicinity of foreland-ward propagating thrusts; that in each of the identified SSDS associations the SSDS of different geometries, except in case of SSDS Association 4, are spatially closely associated within the same sediment unit; that deformed horizons are sandwiched between undeformed horizons and fineness of the host sediments, together, indicate that the liquefaction of sediments was triggered by repetitive earthquake shocks generated due to faulting (cf. Sims, 1975; Hilbert-Wolf, 2009; Pandey et al., 2009; Gibert et al., 2011; Moretti and Ronchi, 2011; Owen et al., 2011). Many scientists favour a vast lateral extension of the deformed horizons as a clue for identifying seismites (Sims, 1975; Obermeier et al., 1990; Owen and Moretti, 2011), however to others, such a criterion is not a mandatory one (Moretti and van Loon, 2014). Occurrence of repetitive earthquake triggers is also suggested by the presence of SSDS in only a few of the horizons of the fine-grained particularly heterolithic facies in the entire sequence (cf. Owen and Moretti, 2011; Moretti and Ronchi, 2011). To examine the relationship between earthquake magnitude and liquefaction of sediment, Castilla and Audemard (2007) have shown that thrusting-induced earthquakes of magnitude between 5.5 and 7 can liquefy sediments within $150 \mathrm{~km}$ of the epicentre. Other authors proposed that an earthquake of magnitude as low as 2-3 is sufficient for liquefaction (Seed and Idris, 1971). The Siwalik basin was well within $150 \mathrm{~km}$ from the Lesser Himalayan thrusts and the north-south trending rifts. The MBT, which possibly was activated during the Siwalik deposition, was at a few $\mathrm{km}$ to the north of the Siwalik Basin. Therefore, Siwalik sediments were presumably easily liquefied by the thrust/rift generated seismicity.

Therefore, both the tectonic and depositional settings of the Siwalik sediments of the study area were favourable for the formation of SSDS. In Association-4 only one variety of deformation structure is present and the morphology of these folds indicates the genetic influence of channel process and slope controlled deformation. 


\section{Conclusions}

The Middle Siwalik sediments in the Lish Valley of the Eastern Himalaya were deposited in an alluvial fan setting. The sedimentary rocks preserve different types of associations of soft-sediment deformation structures. The sedimentation took place during tectonic activities occurred along the Lesser Himalayan Thrusts, the Main Boundary Thrust, the Main Central thrust, the South Tibet Detachment and the north-south trending rifts, which caused repeated seismicity. Both seismic disturbances and deposition in alluvial fan setting at the toe of the mountain where slope breaks were favourable for deformation of unconsolidated sediment, played a role in forming the observed soft-sediment deformation structures (SSDS). Associations of SSDS, their morphology and relations with overlying and underlying strata indicate that all of the associations except one were formed due to seismic disturbance, and that the exception was formed by the depositional process itself perhaps indicating pause of seismic activity during that time. Within the study area thus, seismic genesis of SSDS was paramount above depositional processes within the sedimentary setting.

\section{Acknowledgements}

Abhik Kundu acknowledges the University Grants Commission, India, for the research grant PSW-035/10-11(ERO). Institutional support provided by Dr. Dipak Kar, Principal, Asutosh College is thankfully acknowledged. Patrick Eriksson thanks the University of Pretoria and the National Research Foundation, South Africa for research funding. Abdul Matin acknowledges the DST, Govt. of India research funding (Project No. SR/S4/ES:276/2007).

\section{References}

Aboumaria, K., Zaghloul, M.N., Battaglia, M., Loiacono, F., Puglisi, D., and Aberkan ,M., 2009, Sedimentary processes and provenance of Quaternary marine formations from the Tangier Peninsula (Northern Rif, Morocco): Journal of African Earth Sciences, v. 55, no. 1-2, pp. 10-35.

Acharyya, S.K., 1994, The Cenozoic Foreland Basin and tectonics of the eastern subHimalaya: problems and prospects, in, Kumar, R., Ghosh, S.K., Phadtare, N.R., eds, Siwalik Foreland Basin of Himalaya: Himalayan Geology, v. 15, pp. 3-21.

Acharyya, S.K., and Shastry, M.V.A., 1979, Stratigraphy of the Eastern Himalaya: Himalayan Geology Seminar, New Delhi, Geological Survey of India Miscellaneous Publication, v. 41, no. 1, pp. 49-64.

Allen, J.R.L., 1984, Sedimentary Structures: their Character and PhYsical Basis (unabridged one-volume edition): Developments in Sedimentology, v. 30, Elsevier, New York, 1256 p.

Arita, K., 1983, Origin of the inverted metamorphism of the Lower Himalayas Central Nepal: Tectonophysics, v. 95, pp. 43-60.

Banerji, I., and Banerji, S., 1982, A coalescing alluvial fan model of the Siwalik sedimentation -a case study in the eastern Himalaya: Geological Survey of India, Miscellaneous Publication, v. 41, pp. 1-12.

Bhakuni, S.S., Luirei, K., and Mrinalinee Devi, R.K.., 2012, Soft-sediment deformation in the Middle Siwalik rocks of Arunachal Pradesh, NE Himalaya: Himalayan Geology, v. 33, no. 2, pp. 139-145.

Bhattacharya, H.N., and Bandyopadhaya, S., 1998, Seismites in a Proterozoic tidal succession, Singhbhum, Bihar, India: Sedimentary Geology, v. 119, pp. 239-252.

Bhattacharyya, K. and Mitra, G. 2009, A new kinematic evolutionary model for the growth of a duplex-an example from the Rangit duplex, Sikkim Himalaya, India: Gondwana Research, v. 16, pp. 697-715.

Bose, P.K., Banerjee, S. and Sarkar, S., 1997, Slope-controlled seismic deformation and tectonic framework of deposition of Koldaha Shale, India: Tectonophysics, v. 269, pp. 151-169.

Brozovic, N., and Burbank, D.W., 2000, Dynamic fluvial systems and gravel progradation in the Himalayan foreland: Geological Society of America Bulletin, v. 112, no. 3, pp. 394-412.

Castilla, R.A., and Audemard, F.A., 2007, Sand blows as a potential tool for magnitude estimation of pre-instrumental earthquakes: Journal of Seismology, v. 11, no. 4, pp. 473-487.

Cojan, I., and Thiry, M., 1992, Seismically induced deformation structures in Oligocene shallow marine and eolian coastal sands (Paris Basin): Tectonophysics, v. 206, pp. 79-89.

Collinson, J.D., and Thompson, D.B. 1982, Sedimentary Structures. Allen and Unwin, London, 194p.

Dasgupta, P., 1998, Recumbent flame structures in the Lower Gondwana rocks of the Jharia Basin, India - A plausible origin: Sedimentary Geology, v. 119, pp. 253-361.

DeCelles, P.G., Gehrels, G.E., Quade, J., Ojha, T.P., Kapp, P.A., and Upreti, B.N., 1998, Neogene foreland basin deposits, erosional unroofing and the kinematic history of the Himalayan fold and thrust belt, western Nepal: Geological Society of America Bulletin, v. 110, pp. 2-21.

Demicco, R.V., and Hardie, L.A., 1994, Sedimentary structures and early diagenetic features of shallow marine carbonate deposits: Society of Economic Paleontologists and Mineralogists Atlas Series 1, 255 p.

Døe, T.W., and Dott, R.H.Jr., 1980, Genetic Significance of Deformed Cross Bedding - With Examples from the Navajo and Weber Sandstones of Utah: Journal of Sedimentary Petrology, v. 50, pp. 793-812.

Dzulynski, S., and Smith, A.J., 1963, Convolute lamination, its origin, preservation, and directional significance: Journal of Sedimentary Petrology, v. 33, no. 3, pp. 616627.

Edwards, M.A., and Harrison, T.M. 1997, When did the roof collapse? Late Miocene north-south extension in the High Himalaya revealed by Th$\mathrm{Pb}$ monazite dating of the Khula Kangri granite: Geology, v. 25, no., 6, pp. 543-546.

Gansser, A., 1964, Geology of the Himalayas. Wiley, New York, 289p.

Gibert, L., Alfaro, P., García-Tortosa, F. J., and Scott, G., 2011, Superposed deformed beds produced by single earthquakes (Tecopa Basin, California): Insights into paleoseismology: Sedimentary Geology, v. 235, pp. 148-159.

Harrison, T.M., Copeland, P., Kidd, W.S.F., and Lovera, O.M., 1995, Activation of the Nyainqentanghla shear zone: implications for uplift of the southern Tibetan Plateau: Tectonics, v.14, pp. 658-676.

Hilbert-Wolf, H. L., Simpson, E. L., Simpson, W. S., Tindall, S. E., and Wizevich, M. C., 2009, Insights into syndepositional fault movement in a foreland basin; trends in seismites of Upper Cretaceous Wahweap Formation, Kaiparowits Basin, Utah, USA: Basin Research, v. 21, pp. 856-871.

Huyghe, P., Galy, A., Mugnier, J.L., and France-Lanord, C., 2001, Propagation of the thrust system and erosion in the Lesser Himalaya: geochemical and sedimentological evidence: Geology, v. 29, no. 11, pp. 1007-1010.

Ingram, R.L., 1954, Terminology for thickness of stratification and parting units in sedimentary rocks: Geological Society of America Bulletin, v. 65, pp. 937-938.

Jones, A.P., and Omoto, K., 2000. Towards establishing criteria for identifying trigger mechanisms for soft sediment deformation: a case study of Late Pleistocene lacustrine sands and clays, Onikobe and Nakayamadaira Basins, northeastern Japan: Sedimentology, v. 47, 1211-1226.

Kumar, R., Gill, G.S., and Gupta, L.N., 2005, Earthquake induced structures in Pinjore Formation of Nadah area, Haryana: Journal of The Geological Society of India, v. 65, pp. 346-352.

Kumar, R., Ghosh, S.K., and Sangode, S.J., 2003, Mio-Pliocene sedimentation history in the northwestern part of the Himalayan Foreland Basin, India: Current Science, v. 84, no. 8, pp. 1006-1013.

Kundu, A., 2012, Geometry of the frontal thrust sheets in the Siwalik sequence in the Darjeeling sub-Himalaya, West Bengal, India: Unpublished Ph.D. Thesis, University of Calcutta, Kolkata, India, 165p.

Kundu, A., and Goswami, B., 2008, A note on seismic evidences during the 
sedimentation of Panchet Formation, Damodar Basin, Eastern India: Banspetali Nullah Revisited: Journal of The Geological Society of India, v.7 2. pp. 400-404.

Kundu, A., Matin, A., Mukul, M., and Eriksson, P.G., 2011, Sedimentary facies and soft-sediment deformation structures in the Late MiocenePliocene Middle Siwalik Subgroup, eastern Himalaya, Darjiling district, India: Journal of The Geological Society of India, v. 78, pp. 321-336.

Kundu, A., Matin, A., and Mukul, M., 2012, Depositional environment and provenance of Middle Siwalik sediments in Tista valley, Darjiling District, Eastern Himalaya, India: Journal of Earth System Science, v. 121, no. 1, pp. 73-89.

Leeder, M.R., 1987, Sediment deformation structures and the palaeotectonic analysis of sedimentary basins, with case-study from the Carboniferous of northern England, in, Jones M.E., and Preston R.M.F., eds, Deformation of Sediments and Sedimentary Rocks: Geological Society of London Special Publication, v. 29, pp. 137-146.

Lowe, D.R., 1975, Water escape structures in coarse grained sediments: Sedimentology, v. 22, pp.157-204.

Matin, A., and Mukul, M., 2010, Phases of deformation from cross-cutting structural relationships in external thrust sheets: Insights from smallscale structures in the Ramgarh thrust sheet, Darjiling Himalaya, West Bengal: Current Science, v. 99, no. 10, pp. 1369-1377.

McKee, E.D., Reynolds, M.A., and Baker, C.H., 1962, Experiments on intraformational recumbent folds in crossbedded sand: USGS Professional Paper, 450D, pp. D155D160.

McQuarrie, N., Robinson, D., Long, S., Tobgay, T., Grujic, D., Gehrels, G., and Ducea, M., 2008, Preliminary stratigraphic and structural architecture of Bhutan: implications for the along strike architecture of the Himalayan system: Earth and Planetary Science Letters, v. 272, pp. 105-117.

Meigs, A.J., Burbank, D.W., and Beck, R.A., 1995, Middle-late Miocene (>10 Ma) formation of the Main Boundary thrust in the western Himalaya: Geology, v. 23, no. 5, pp. 423-426.

Mills, P.C., 1983, Genesis and diagnostic value of soft-sediment deformation structures - a review: Sedimentary Geology, v. 35, pp. 83-104.

Moretti, M., Alfaro, P., Caselles, O., and Canas, J.A., 1999, Modelling seismites with a digital shaking table: Tectonophysics, v. 304, pp. 369383.

Moretti, M., and Ronchi, A., 2011, Liquefaction features interpreted as seismites in the Pleistocene fluvio-lacustrine deposits of the Neuquén Basin (Northern Patagonia): Sedimentary Geology, v. 235, pp. 200-209.

Moretti, M., and Van Loon, A.J., 2014, Restrictions to application of 'diagnostic' criteria for recognizing ancient seismites: Journal of Palaeogeography, v. 3, pp. 162-173.

Mukhopadhyay, D.K., and Mishra, P., 1999, A balanced cross section across the Himalayan foreland belt, the Punjab and Himachal foothills: A reinterpretation of structural styles and evolution: Proceedings of the Indian Academy of Science (Earth and Planetary Sciences), v. 108, pp. 189-205.

Mukul, M., 2000, The geometry and kinematics of the Main Boundary Thrust and related neotectonics in the Darjiling Himalayan fold-and-thrust belt, West Bengal, India: Journal of Structural Geology, v. 22, pp. 1261-1283.

Nakata, T., 1989, Active faults of the Himalaya of India and Nepal: Geological Society of America Special Paper, v. 232, pp. 243-264.

Nakayama, K., and Ulak, P.D., 1999, Evolution of fluvial style in the Siwalik Group in the foothills of the Nepal Himalaya: Sedimentary Geology, v. 125 , pp. 205-224.

Neuwerth, R., Suter, F., Guzman, C.A., and Gorin, G.E., 2006, Soft-sediment deformation in a tectonically active area: The Plio-Pleistocene Zarzal Formation in the Cauca Valley (Western Colombia): Sedimentary Geology, v. 186 , pp. $67-88$

Obermeier, S.F., Jacobson, R.B., Smoot, J.P., Weems, R.E., Gohn, G.S., Monroe, J.E., and Powars, D.S., 1990, Earthquake-induced liquefaction features in the coastal setting of South Carolina and in the fluvial setting of the New Madrid seismic zone: United States Geological Survey Professional Paper, 1504: 44.

Owen, G., 1995, Soft-sediments deformation in Upper Proterozoic Torridonian
Sandstones (Applecross Formation) at Torridon, Northwest Scotland: Journal of Sedimentary Research, v. 65, pp. 495-504.

Owen, G., 1996, Experimental soft-sediment deformation: Structures formed by liquefaction of unconsolidated sands and some ancient examples: Sedimentology, v. 43, pp. 279-293.

Owen, G., and Moretti, M., 2011, Identifying triggers for liquefaction induced soft-sediment deformation in sands: Sedimentary Geology, v. 235, pp.141147.

Owen, G., Moretti, M., and Alfaro, P., 2011, Recognising triggers for softsediment deformation: Current understanding and future directions: Sedimentary Geology, v. 235, pp. 133-140.

Pandey, P., Kumar, R., Suresh, N., Sangode, S.J., and Pandey, A.K., 2009, Soft-Sediment Deformation in Contemporary Reservoir Sediment: A Repository of Recent Major Earthquake Events in Garhwal Himalaya: The Journal of Geology, v. 117, pp. 200-209

Plint, A.G., and Wadsworth, J.A., 2003, Sedimentology and palaeogeomorphology of four large valley systems incising delta plains, western Canada Foreland Basin: implications for mid-Cretaceous sealevel changes: Sedimentology, v. 50, pp. 11471186.

Raina, V.K., 1976, The Rangit Tectonic Window - stratigraphy, structure \& tectonic interpretation and its bearing on the regional stratigraphy: Geological Survey of India Miscellaneous Publication, v. 41, pp. 36-42.

Raiverman, V., 2002, Foreland sedimentation in Himalayan tectonic regime: a Reply: -look at the orogenic process: Bishen Singh Mahendra Pal Singh, Dehradun, India: 378p

Rajchl, M., 1999, Structures due to Synsedimentary Deformations in Sediments of the Bílina Delta (Miocene, Most Basin, Czech Republic): Geolines, v. 8, pp. 57.

Ranjan, N., and Banerjee, D.M., 2009, Central Himalayan crystallines as the primary source for the sandstone-shale suites of the Siwalik Group: New geochemical evidence: Gondwana Research, v. 16, pp. 687-696.

Reineck, H.E., and Singh, I.B., 1980, Depositional sedimentary environments: SpringerVerlag, Berlin-Heidelberg, 551p.

Rodriguez-Pascua, M.A., Calvo, J.P., De Vicente, G. \& Gómez-Gras, D., 2000, Soft sediment deformation structures interpreted as seismites in lacustrine sediments of the Prebetic Zone, SE Spain, and their potential use as indicators of earthquake magnitudes during the Late Miocene: Sedimentary Geology, v. 135, pp. 117-135.

Røe, S.L., and Hermansen, M., 2006, New aspects of deformed cross-strata in fluvial sandstones: examples from Neoproterozoic formations in northern Norway: Sedimentary Geology, v. 186, pp. 283-293.

Saha, D., 2013, Lesser Himalayan sequences in Eastern Himalaya and their deformation: Implications for Paleoproterozoic tectonic activity along the northern margin of India: Geoscience Frontiers, v. 4, pp. 289-304.

Samaila, N.K., Abubakar, M.B., Dike, E.F.C., Obaje, N.G., 2006,. Description of softsediment deformation structures in the Cretaceous Bima Sandstone from the Yola Arm, Upper Benue Trough, Northeastern Nigeria: Journal of African Earth Sciences, v. 44, pp. 66-74.

Sangode, S.J., Kumar, R., and Ghosh, S.K., 1996, Magnetic polarity stratigraphy of the Siwalik sequence of Haripur area (H.P.), NW Himalaya: Journal of the Geological Society of India, v. 47, pp. 683-704.

Sarkar, S., Banerjee, S. and Chakraborty, S., 1995, Synsedimentary seismic signatures in the Mesoproterozoic Koldaha Shale, Kheinjua Formation, central India: Indian Journal of Earth Sciences, v. 22, pp. 158-164.

Sarkar, S., Choudhuri, A., Banerjee, S., van Loon, A.J., Bose, P.K., 2014, Seismic and non-seismic soft-sediment deformation structures in the Proterozoic Bhander Limestone, central India: Geologos, v. 20, pp. 7993.

Schnellmann, M., Anselmetti, F.S., Giardini, D., Mckenzie, J.A., and Ward, S.N., 2002, Prehistoric earthquake history revealed by lacustrine slump deposits: Geology, v. 30, no. 12, pp. 1131-1134.

Seilacher, A., 1969, Fault-graded beds interpreted as seismites: Sedimentology, v. 13 , pp. $155-159$.

Seed, H.B., and Idriss, I.M., 1971, Simplified procedure for evaluating soil liquefaction potential: Journal of the Soil Mechanics and Foundations Division, v. 97, pp. 12491273. 
Selley, R.C., 1970, Origin of disturbed bedding in Torridon Group sandstones: Scottish Journal of Geology, v. 6, pp. 409-411.

Sharma, M., Sharma, S., Shukla, U.K., and Singh, I.B., 2002, Sandstone body architecture and stratigraphic trends in the Middle Siwalik succession of the Jammu area, India: Journal of Asian Earth Sciences, v. 20 , pp. $817-828$.

Siegenthaler, C., Finger, W., Kelts, K., and Wang, S., 1987, Earthquake and seiche deposits in Lake Lucerne, Switzerland: Eclogae Geologicae Helvetiae, v. 80, pp. 241-260.

Sims, J.D., 1975, Determining earthquake recurrence intervals from deformational structures in young lacustrine sediments. Tectonophysics, v. 29: pp. 141-152.

Simms, M.J., 2003, Uniquely extensive seismite from the latest Triassic of the United Kingdom: Evidence for bolide impact? Geology, v. 31, no. 6, pp. 557-560.

Singh, J., Sharma, U., and Kumar, R. 2007, Soft-sediment deformation in the Morni area, NW Sub-Himalaya: Current Science, v. 98, no. 8, pp. 1151-1155.

Sinha Roy, S., 1967, Tectonic evolution of the Darjiling Himalayas: Quarterly Journal of the Geological Minning and Metallurgical Society of India, v. 48, 167-178.

Spalluto, L., Moretti, M., Festa, V., and Tropeano, M., 2007, Seismicallyinduced slumps in Lower-Maastrichtian peritidal carbonates of the Apulian Platform (southern Italy): Sedimentary Geology, v. 196, pp. 8198 .

Stow, D.A.V. 1981, Fine-grained sediments terminology: Quarterly Journal of Engineering Geology and Hydrogeology London, v. 14, pp. 243-244.

Tasgin, C.K., and Turkmen, I., 2009, Analysis of soft-sediment deformation structures in Neogene fluvio-lacustrine deposits of Çaybaðý Formation, Eastern Turkey: Sedimentary Geology, v. 218, pp. 16-30.

Thomas, J.V., Parkash, B., and Mohindra, R., 2002, Lithofacies and palaeosol analysis of the Middle and Upper Siwalik Groups (Plio-Pleistocene), Haripur-Kolar section, Himachal Pradesh, India: Sedimentary Geology, v. 150 , pp. $343-366$.

Valdiya, K.S., 1980, Geology of the Kumaon Lesser Himalaya: Wadia Institute of Himalayan Geology, Dehra Dun, India, 291p.

Van Loon, A.J., 2009, Soft-sediment deformation structures in siliciclastic sediments: An overview: Geologos, v.15, no. 1, pp. 3-55.

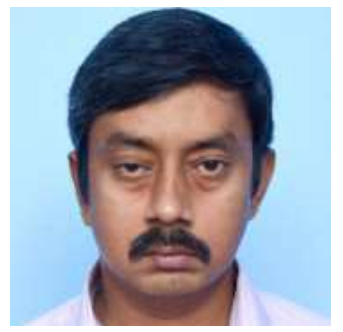

Abhik Kundu is presently the Head of the Department of Geology at Asutosh College, Kolkata, India. He is a doctorate from the University of Calcutta, India. Besides his teaching responsibilities he is also involved in research activities. Dr. Kundu takes interests in sedimentology, structural geology and planetary geology. Presently he is working in the eastern Himalaya and also on geology of Mars.

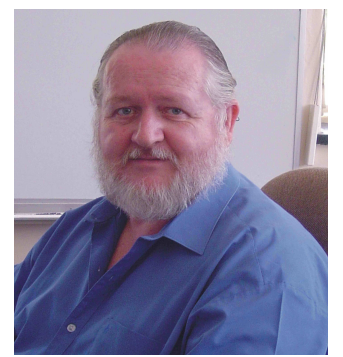

Patrick Eriksson is Emeritus Professor and Chair of Geology at the University of Pretoria, South Africa. He holds doctorates from the University of KwaZulu-Natal and the LudwigMaximilians University in Munich (Dr rer nat habil). His interests are in Precambrian sedimentation systems, microbial mat features in clastic sediments, basin analysis and secular change in the sedimentary record.
Wang, P., Zhang, B., Qiu, W., and Wang, J., 2010, Soft-sediment deformation structures from the Diexi paleo-dammed lakes in the upper reaches of the Minjiang River, east Tibet: Journal of Asian Earth Sciences, v. 40, no. 4, pp. 865-872.

Went, D.J., 2005, Pre-vegetation alluvial fan facies and processes: an example from the Cambro-Ordovician Rozel Conglomerate Formation, Jersey, Channel Islands:Sedimentology, v. 52, pp. 693-713.

Wheeler, R.L. 2002, Distinguishing seismic from nonseismic soft-sediment structures: Criteria from seismic-hazard analysis, in, Ettensohn, F.R., Rast, N., and Brett, C.E., eds, Ancient Seismites: Geological Society of America, Special Paper, v. 359, pp. 1-11.

White, N.M., Parrish, R.R., Bickle, M.J., Najman, Y.M.R., Burbank, D., and Maithani, A.,2001, Metamorphism and exhumation of the NW Himalaya constrained by $\mathrm{U}-\mathrm{Th}-\mathrm{Pb}$ analyses of detrital monazite grains from early foreland basin sediments. Journal of the Geological Society, v. 158, pp. 625-635.

Williams, G.E., 1970, Origin of disturbed bedding in Torridon Group sandstones: Scottish Journal of Geology, v. 6, pp. 409-411.

Yeats, R., and Lillie, S., 1991, Contemporary tectonics of the Himalayan frontal fault system: folds, blind thrusts and 1905 Kangra earthquake: Journal of Structural Geology, v. 13, pp.215-225.

Yin, A., 2006, Cenozoic tectonic evolution of the Himalayan orogen as constrained by along-strike variation of structural geometry, exhumation history, and foreland sedimentation: Earth-Science Reviews, v. 76, pp. 1-131.

Yin, A., Harrison, .T.M., 2000, Geologic evolution of the Himalayan-Tibetan orogen: Annual Review of Earth and Planetary Sciences, v. 28, pp. 211280

Zielinski, T., Van Loon, A.J., 1999a, Subaerial terminoglacial fans I: a semiquantitative sedimentological analysis of the proximal environment: Geologie En MijnbouwNetherlands Journal of Geosciences, v. 77, pp. 1-15.

Zielinski, T., Van Loon, A.J., 1999b, Subaerial terminoglacial fans II: a semiquantitative sedimentological analysis of the middle and distal environments: Geologie En Mijnbouw-Netherlands Journal of Geosciences, v. 78, pp. 73-85.

Zielinski, T., Van Loon, A.J., 2000, Subaerial terminoglacial fans IIII: overview of sedimentary characteristics and depositional model: Geologie En Mijnbouw Netherlands Journal of Geosciences, v. 79, pp. 93-107.

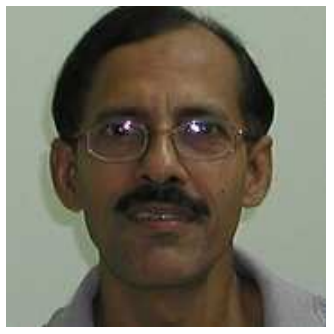

Abdul Matin is presently Professor of Geology at the University of Calcutta, India. He received his doctorate degree from the Indian School of Mines, Dhanbad, India. Besides his 32 years of teaching experience he is involved in research in the field of structural geology and sedimentology. Presently he works in the eastern Himalaya and also in Precambrian terrains of Central India and West Bengal. 